\title{
Internationale Kapitalströme illegaler Herkunft
}

Flux internationaux de capitaux d'origine illicite

La Suisse face aux nouvelles stratégies

\section{Paolo Bernasconi}

\section{OpenEdition}

\section{Journals}

Édition électronique

URL : http://journals.openedition.org/sjep/1155

DOI : 10.4000/sjep.1155

ISSN : 1663-9677

Éditeur

Institut de hautes études internationales et du développement

Édition imprimée

Date de publication : 1 janvier 1990

Pagination : 199-229

ISSN : 1660-5926

Référence électronique

Paolo Bernasconi, « Internationale Kapitalströme illegaler Herkunft », Schweizerisches Jahrbuch für Entwicklungspolitik [En ligne], 9 | 1990, mis en ligne le 31 mars 2013, consulté le 08 septembre 2020 URL : http://journals.openedition.org/sjep/1155; DOI : https://doi.org/10.4000/sjep.1155

Ce document a été généré automatiquement le 8 septembre 2020

(C) The Graduate Institute 


\section{Internationale Kapitalströme illegaler Herkunft}

Flux internationaux de capitaux d'origine illicite

La Suisse face aux nouvelles stratégies

\section{Paolo Bernasconi}

\section{NOTE DE L'ÉDITEUR}

Volltext auf Französisch in Annuaire suisse de politique de développement: „Flux internationaux de capitaux d'origine illicite", http://aspd.revues.org/1322.

\section{AUTEUR}

\section{PAOLO BERNASCONI}

Avocat, Lugano ; Chargé de cours aux Universités de St-Gall et de Zurich 